\title{
Jaboticaba (Myrciaria jaboticaba (Vell.) Berg.) peel improved triglycerides excretion and hepatic lipid peroxidation in high-fat-fed rats
}

Consumo de casca de jabuticaba (Myrciaria jaboticaba

(Vell.) Berg.) melhorou a excreção de triglicerídeos

e a peroxidação lipídica hepática de ratos

alimentados com dieta hiperlipídica

\author{
Ângela Giovana BATISTA ${ }^{1}$ \\ Sabrina Alves LENQUISTE' \\ Carolin MOLDENHAUER ${ }^{2}$ \\ Juliana Teixeira GODOY ${ }^{1}$ \\ Soely Maria Pissini MACHADO REIS ${ }^{1}$ \\ Mário Roberto MARÓSTICA JÚNIOR
}

\section{Objective}

The aim of this study was to evaluate the influence of high-fat diets with $1 \%, 2 \%$, and $4 \%$ freeze-dried jaboticaba peel on the serum, liver, and fecal lipid profile of obese rats.

\section{Methods}

Thirty male Sprague-Dawley rats were divided into 5 groups. Obesity was induced in four groups using a high-fat diet (35\% lipids). One group was used as a high-fat diet control (High-fat group - HF). The other three high-fat-diet groups were given 1\%, 2\%, and 4\% freeze-dried jaboticaba peel (High-Fat Jaboticaba - HFJ1, HFJ2, and HFJ4, respectively) in the last 40 experimental days. Blood and the liver were collected after 70 days of treatment and feces were collected in the last experimental week. Total cholesterol, triglycerides, and lipids were measured in the serum, liver, and dried feces.

\footnotetext{
1 Universidade Estadual de Campinas, Faculdade de Engenharia de Alimentos, Departamento de Alimentos e Nutrição. R. Monteiro Lobato, 80, Cidade Universitária, 13083-862, Campinas, SP, Brasil. Correspondência para/Correspondence to: MR MARÓSTICA JÚNIOR. E-mail: <mmarostica@gmail.com>.

2 Christian-Albrechts-University, Faculty of Agricultural and Nutritional Science. Kiel, Germany.
} 


\section{Results}

In the second phase of the experiment, HFJ4 group consumed more food and calories than the high-fat group. Total serum cholesterol and triglyceride levels did not differ in the experimental groups. HFJ2 group had the highest hepatic and fecal lipid contents compared with the group fed a diet with normal fat content (N), but low hepatic lipid peroxidation. HFJ4 group had the highest mean hepatic and fecal cholesterol levels. Hepatic triglyceride levels did not differ among the groups, and groups HFJ1 and HFJ4 presented the highest fecal triglyceride content.

\section{Conclusion}

The amounts of jaboticaba peel used by this study did not protect against hepatic steatosis or undesired levels of other studied lipids, but it did increase fecal triglycerides. Lipid peroxidation in the liver decreased in the HFJ2 group.

Indexing terms: Myrciaria jaboticaba (Vell.) Berg. Cholesterol. Triglycerides. Lipid profile. Obesity.

\section{R E S U M O}

\section{Objetivo}

O objetivo deste estudo foi avaliar o efeito de dietas hiperlipídicas adicionadas de 1\%, 2\% e 4\% de casca de jabuticaba liofilizada sobre os perfis lipídicos do fígado, soro e fezes de ratos.

\section{Métodos}

Trinta ratos, machos, Sprague-Dawley, foram divididos em cinco grupos. A obesidade foi induzida em quatro grupos, com dieta hiperlipídica ou High-Fat - HF (35\% de lipídeos). Três desses grupos receberam a dieta hiperlipídica adicionada de 1\%, 2\% e 4\% de casca de jabuticaba liofilizada (Jabuticaba - HFJ1, HFJ2 e HFJ4, respectivamente) nos últimos 40 dias de experimento. Sangue e fígado foram coletados após 70 dias de tratamento e as fezes na última semana experimental. Colesterol e triglicerídeos totais foram avaliados no soro, fígado e fezes secas, bem como lipídeos totais.

\section{Resultados}

No segundo período do experimento, a ingestão dietética e energética dos animais HFJ4 foi maior em relação ao grupo High-Fat. Não houve diferença significativa entre os grupos experimentais para colesterol total e triglicerídeos séricos. O grupo HFJ2 demonstrou maiores níveis de lipídeos hepáticos e fecais em relação a N, apesar de a peroxidação lipídica ter diminuído nesse grupo. O HFJ4 mostrou a maior média de colesterol hepático e fecal. Não houve diferenças significativas para triglicerídeos hepáticos, e os grupos HFJ1 e HFJ4 excretaram mais triglicerídeos pelas fezes.

\section{Conclusão}

As doses utilizadas de casca de jabuticaba não mostraram efeitos benéficos contra a esteatose hepática ou outro parâmetro lipídico avaliado, com exceção para a excreção de triglicerídeos. O índice de peroxidação lipídica hepática diminuiu nos ratos alimentados com 2\% de casca de jabuticaba liofilizada.

Termos de indexação: Myrciaria jaboticaba (Vell.) Berg. Colesterol. Triglicerídeos. Perfil lipídico. Obesidade.

\section{INTRODUCTION}

Myrciaria jaboticaba (Vell.) Berg., commonly known as Brazilian berry, is a plant native to South America. It produces globose fruits with a deep purple peel and sweet white pulp known as jaboticaba. Its popularity in Brazil is comparable to that of grapes in Europe or in the United States of America. Although not widely consumed, most of its polyphenols, such as ellagic acid, quercetin, and anthocyanins are concentrated in the peel, which has an expressive antioxidant activity ${ }^{1-3}$.

High-polyphenol/anthocyanin diets reduce Cardiovascular Diseases (CVD) because they affect the regulation of lipid metabolism ${ }^{4-6}$. These diets may reduce total serum cholesterol and triglyceride levels ${ }^{7}$ and increase High Density Lipoproteincholesterol (HDL-cholesterol) levels in obese 
animals ${ }^{6}$. The mechanism underlying these findings may regard the ability of these diets to increase biliary cholesterol excretion and fecal lipid excretion, reducing plasma lipid levels 5 . Anthocyanins may influence the expression of hepatic enzymes. One such example is the powerful anthocyanin called cyanidin 3-glucoside, capable of suppressing hepatic enzymes involved in the synthesis of fatty acids and triglycerides, which could increase hepatic $\beta$-oxidation and decrease fatty acid synthesis. These mechanisms may also promote weight and fat loss in obese rats $^{8-10}$.

Jaboticaba peel is also a source of dietary fibers $^{3,11}$, nutrients with hypocholesterolemic role. High-polyphenol and high-fiber diets are capable of reducing total cholesterol and Low Density Lipoprotein-cholesterol (LDL-cholesterol) 4,12, suggesting that both substances may act synergistically on the regulation of blood lipids. Moreover, diets supplemented with $1 \%$ or $2 \%$ freeze-dried jaboticaba peel improved the antioxidant capacity of rat plasma, indicating the potential of freeze-dried jaboticaba peel compounds to attenuate oxidative stress ${ }^{13}$ and related damages ${ }^{14}$

Previous in vivo investigations on the addition of $1 \%, 2 \%$, and $4 \%$ freeze-dried jaboticaba peel to the diets of obese animals reported that it could not effectively reduce energy intake, weight gain, and body fat ${ }^{15}$. However, obese animals fed diets with $2 \%$ and $4 \%$ freeze-dried jaboticaba peel showed an increase in HDL-cholesterol level and a decrease in insulin levels ${ }^{6}$. Changes in hepatic lipid content and their excretion may have promoted these findings. Hence, the aim of this study was to assess the influence of high-fat diets with added $1 \%, 2 \%$ and $4 \%$ freeze-dried jaboticaba peel on the serum, liver, and fecal lipid profile of obese rats.

\section{METHODS}

Thirty weaned, male, Sprague-Dawley (SD) rats weighing $58 \pm 18.77 \mathrm{~g}$ were obtained from the
Centro Multidisciplinar para investigação Biológica (CEMIB, Multidisciplinary Center for Biological Research) of Universidade Estadual de Campinas (Unicamp). This experiment was approved by the Animal Research Ethics Committee (CEUAVUnicamp) under protocol number 2,226-1. The study was performed as required by the Colégio Brasileiro de Experimentação Animal (COBEA, Brazilian Council on Animal Experimentation). The animals were randomly assigned to five groups $(n=6)$ and kept in individual cages with free access to food and water, temperature of $22 \pm 1^{\circ} \mathrm{C}$, humidity of $60 \%-70 \%$, and controlled light and dark cycles of 12 hours throughout the experiment.

Two control diets were given during the experiment: a diet with normal-fat content $(\mathrm{N})$, (AIN-93G), prepared as recommended by the American Institute of Nutrition ${ }^{16}$, and one with High-Fat (HF) content, (AIN-93G with 35\% fat by weight, being $4 \%$ soybean oil and $31 \%$ lard). The study also included another three experimental diets made by adding different concentrations $\left(1 \%, 2 \%\right.$, and $\left.4 \% w^{-1}\right)$ of freeze-dried jaboticaba peel to the high-fat diet mentioned above. All diets were adjusted to have the same total fiber content. Table 1 shows the anthocyanin and dietary fiber contents ${ }^{3}$ of freeze-dried jaboticaba peel. The two control groups, $\mathrm{N}$ and HF, were fed the respective diets throughout the experiment. HFJ1, HFJ2, and HFJ4 groups were fed the HF diet during the first 4 weeks followed by diets with the respective amounts of freeze-dried jaboticaba peel until the end of 10 weeks. Food intake was monitored every 2 days and weight gain once a week.

Freeze-dried jaboticaba peel is a powder made by freeze-drying $M$. jaboticaba peels, as described elsewhere ${ }^{3}$. Freeze-dried jaboticaba peel contains the following compounds of interest: soluble fibers (5\%), insoluble fibers $(20 \%)$, total polyphenols (556.30 $\left.\mathrm{g} \mathrm{GAE} \mathrm{kg}^{-1}\right)$,

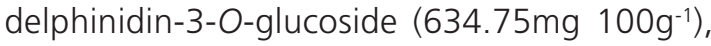

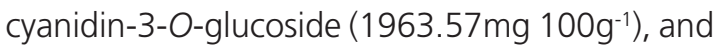

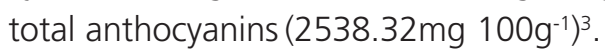

Blood was obtained from the rats by decapitation after a 12-hours fasting. After 
Table 1. Composition of the experimental diets $\left(\mathrm{g} \mathrm{kg}^{-1}\right)$. Campinas (SP), Brazil, 2011.

\begin{tabular}{|c|c|c|c|c|c|}
\hline Composition & $\mathrm{N}$ & $\mathrm{HF}$ & HFJ1 & HFJ2 & HFJ4 \\
\hline Calories $\left(\mathrm{kcal} \mathrm{kg}^{-1}\right)^{*}$ & 4,252 & 5,834 & 5,809 & 5,772 & 5,784 \\
\hline Casein (78\% protein) & 153.85 & 153.85 & 153.85 & 153.85 & 153.85 \\
\hline Corn starch & 426.63 & 249.82 & 249.82 & 249.82 & 249.82 \\
\hline Maltodextrin & 141.68 & 82.91 & 82.91 & 82.91 & 82.91 \\
\hline Sucrose & 107.33 & 62.92 & 62.92 & 62.92 & 62.92 \\
\hline Soybean oil & 70.00 & 40.00 & 40.00 & 40.00 & 40.00 \\
\hline Lard & - & 310.00 & 310.00 & 310.00 & 310.00 \\
\hline Cellulose & 50.00 & 50.00 & 47.50 & 45.00 & 40.00 \\
\hline Mineral mix ${ }^{* *}$ & 35.00 & 35.00 & 35.00 & 35.00 & 35.00 \\
\hline Vitamin mix ${ }^{* *}$ & 10.00 & 10.00 & 10.00 & 10.00 & 10.00 \\
\hline L-Cystine & 3.00 & 3.00 & 3.00 & 3.00 & 3.00 \\
\hline Choline bitartrate & 2.50 & 2.50 & 2.50 & 2.50 & 2.50 \\
\hline FJP $P^{* * *}$ & - & - & 10.00 & 20.00 & 40.00 \\
\hline Total anthocyanins ${ }^{3}$ & 0 & 0 & 259.83 & 519.66 & 1039.33 \\
\hline Soluble fibers ${ }^{3}$ & 0 & 0 & 0.5 & 1.0 & 2.0 \\
\hline Insoluble fibers ${ }^{3}$ & 0 & 0 & 2.0 & 4.0 & 8.0 \\
\hline
\end{tabular}

Note: *Energy values determined by the Isoperibol Calorimeter 1261 equipped with 1108 oxygen bomb (Parr Instrument Co, Moline, IL). ${ }^{* *}$ Reeves et al. ${ }^{16} \cdot{ }^{* * *}$ FJP: Freeze-dried Jaboticaba Peel. ${ }^{3}$ Reference. N: Normal diet (AIN-93G) group; HF: High-Fat control diet group; HFJ1: High-Fat diet + $1 \%$ FJP; HFJ2: High-Fat diet + 2\% FJP; and HFJ4: High-Fat diet + 4\% FJP.

collection, the blood samples were centrifuged at 4000rpm for 20 minutes. Serum was collected and stored at $-80^{\circ} \mathrm{C}$ until analyses. The livers were removed, rinsed, frozen, and dried in a freezedryer (LP1010, Liobras, São Carlos, São Paulo, Brazil). The livers were manually ground and kept at $-80^{\circ} \mathrm{C}$ until analyses. The feces were collected in the last 7 days of the experiment, dried in a $65^{\circ} \mathrm{C}$ oven with forced circulation for $24 \mathrm{~h}$, manually ground, and kept at $-20^{\circ} \mathrm{C}$ until analyses.

\section{Biochemical analyses}

Total lipids: liver lipid content was determined by the Bligh and Dyer method ${ }^{17}$ and total fecal lipid content was determined by a Soxhlet extractor and petroleum ether ${ }^{18}$.

Lipid hydroperoxide assay: determination of hydroperoxides produced by primary lipid autoxidation in freeze-dried liver was preceded by modified lipid extraction ${ }^{17}$. Three milliliters of the extract containing chloroform and lipids were used for hydroperoxide analysis ${ }^{18}$. The peroxide value was measured as recommended by the official method, which is based on the oxidation of iodide into iodine by peroxides in the sample. The hydroperoxide concentration of each sample in $\mathrm{mEq} \mathrm{kg}{ }^{-1}$ was calculated based on the amount of lipids found.

Cholesterol and triglyceride analyses: liver and fecal lipids were extracted as recommended by Folch ${ }^{19}$. The total cholesterol and triglyceride contents of the serum and extracts were determined by enzyme assay kits (Laborlab, São Paulo, Brazil).

Fecal $\mathrm{pH}$ : dried feces was diluted with deionized water (25 $\mathrm{mg} \mathrm{mL}^{-1}$ ) and homogenized. While stirred, the $\mathrm{pH}$ was measured by a $\mathrm{pH}$ meter (Tecnal model TEC-5, Piracicaba, SP, Brazil)4.

\section{Statistical analyses}

Body weight, weight gain and food/calorie intake were treated by two-way Analysis of Variance (Anova) and the Bonferroni test, a posteriori $(p<0.05)$. Total food intake, total weight gain, lipid profile, dry fecal weight, lipid peroxidation, and $\mathrm{pH}$ were treated as follows: parametric data by one-way Anova followed by 
the Tukey's multiple comparisons test; nonparametric data by the Kruskal-Wallis' and Dunn's multiple comparisons tests. The significance level was set at $p<0.05$. The parametric results were expressed as means \pm Standard Error of the Mean (SEM) and the nonparametric results as medians and ranges. The data were treated by the software GraphPad Prism 5.0 (GraphPad Software, Inc. La Jolla, CA, USA).

A

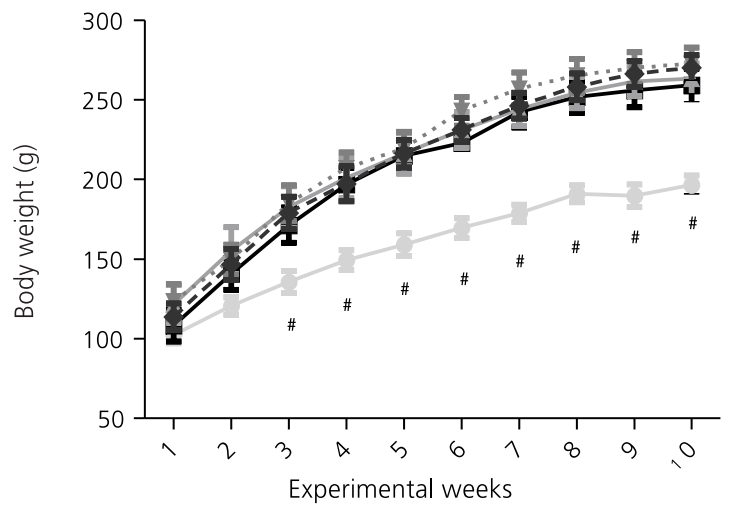

$\rightarrow \mathrm{N} \rightarrow \mathrm{HF} \simeq \mathrm{HFJ1} \cdots \mathrm{WHFJ2} \rightarrow \mathrm{HFJ4}$

\section{RE S U L T S}

The serum and liver were collected after 40 days of dietary treatment and the feces in the last week of intervention. The lipid profiles of the samples were determined. As detailed below, the diets with $1 \%$ and $4 \%$ jaboticaba peel increased triglyceride excretion, although no changes were observed in the liver or serum.

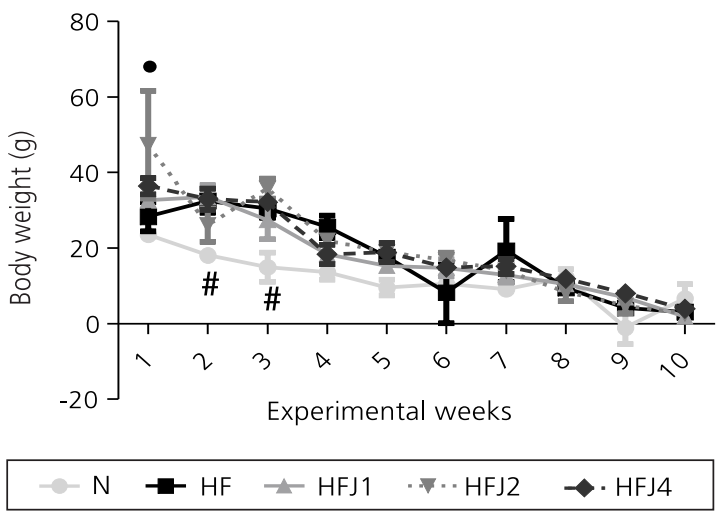

C

D

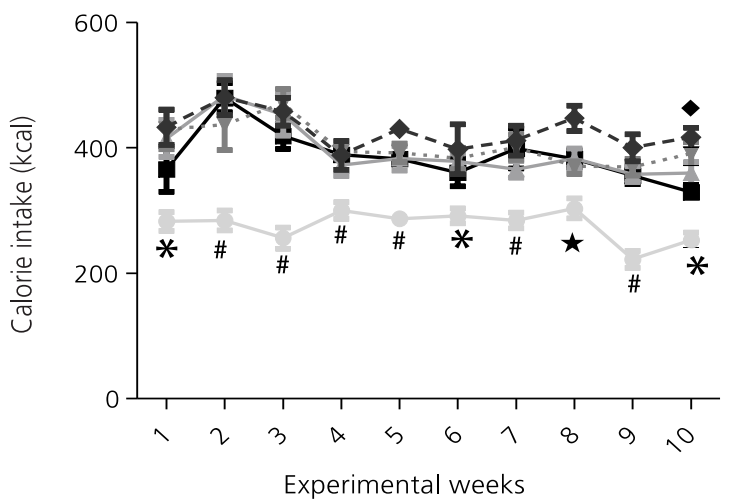

Experimental weeks

Figure 1. Body weight (A), weight gain (B), food intake (C) and calorie intake (D) of the experimental rats during the 10 experimental weeks Campinas (SP), Brazil, 2011.

Note: N: Normal-fat diet (AIN-93G) group; HF: High-Fat control diet group; HFJ1: animals fed HF diet + 1\% Freeze-dried Jaboticaba Peel (FJP); HFJ2: animals fed HF diet + 2\% FJP; and HFJ4: HF + 4\% FJP. Data was treated by two-way Analysis of Variance (Anova) and the Bonferroni post-hoc test; "Indicates that $\mathrm{N}$ group differed from groups fed HF, \#= N differed from the groups fed FJP; $\star=N$ differed from the HFJ4 group; $\bullet=$ HFJ2 and $\bullet=$ HFJ4 differed from the HF group $(p<0.05)$. All data were expressed as mean \pm Standard Error of the Mean (SEM) $(n=6)$. 
Body weight, food intake and fecal parameters: The experimental groups did not differ ( $p>0.05$ ) concerning total weight gain (117.6g to $192.8 \mathrm{~g}$ ) and total food intake $(650.47 \mathrm{~g}$ to $745.16 \mathrm{~g}$ ). However, in the second phase of the experiment (last 6 weeks), food intake of the HFJ4 group (441.02g) was higher than that of the HF group (378.84g). The animals fed the highfat diets presented higher body weights from experimental week five $(p<0.001$, Figure $1 \mathrm{~A})$ and weight gain was similar in the second phase of the experiment ( $p>0.05$, Figure 1B). The HFJ4 group consumed more food than the HF group on the last week $(p<0.05$, Figure $1 C)$. The calorie intake of $\mathrm{N}$ group was lower than those of $\mathrm{HF}$ and HFJ groups throughout the experiment except for week eight, when it differed only from that of HFJ4 group. The calorie intake of HFJ4 group in the last week was also higher than that of HF group ( $p<0.05$, Figure 1D).

Table 2 shows that the animals given freeze-dried jaboticaba peel showed a dosedependent response to anthocyanin and soluble fiber $(p<0.001)$. In addition, higher food intake by HFJ4 group resulted in higher total fiber intake, when compared with HF group $(p<0.05)$. Soluble fiber intake may have contributed to the higher fecal dry weight of HFJ2 and HFJ4 groups in last week. The fecal pH of HF, HFJ1 and HFJ2 groups, were lower than that of $\mathrm{N}$ group $(p<0.001)$. HFJ2 group had the lowest fecal pH (Table 2).

Serum analyses: Total serum cholesterol (69.24mg dL-1 to $80.38 \mathrm{mg} \mathrm{dL}^{-1}$ ) and triglyceride levels $\left(39.67 \mathrm{mg} \mathrm{dL}^{-1}\right.$ to $49.49 \mathrm{mg} \mathrm{dL}^{-1}$ ) did not differ among the experimental groups ( $p>0.05$ ).

Total lipid analyses: The animals fed the high-fat diet had higher hepatic lipid content, especially HFJ2 group, which had the highest mean relative to $\mathrm{N}$ group. The hepatic lipid contents of the groups fed the high-fat diets ( $\mathrm{HF}$, HFJ1, HFJ2, and HFJ4) did not differ. As expected, lipid excretion was higher in all high-fat-diet groups and highest in HFJ2 group, which was different from $\mathrm{N}$ group and similar to $\mathrm{HF}$ group (Figure 2A and 2B).

Liver and feces cholesterol analyses: Differently from $\mathrm{N}$ group, HFJ4 group had the highest mean hepatic and fecal cholesterol levels, similar to those of HF group. On the other hand, the hepatic cholesterol levels of HFJ1 and HFJ4 groups were generally lower (Figure 2C and 2D). Except for HFJ2 group, the groups fed high-fat diets also excreted more cholesterol than $\mathrm{N}$ group $(p<0.05)$.

Triglyceride analyses: Hepatic triglycerides did not differ ( $p>0.05$ ) among the groups, but according to their absolute values, animals fed high-fat diets had higher liver triglyceride contents than animals in N group (Figure 2E). HFJ1 and HFJ4 groups presented higher fecal triglycerides than HF group $(18.55 \%$ and $47.22 \%$ higher, respectively; $p<0.05)$. The fecal triglyceride contents of HFJ4 and $\mathrm{N}$ groups were similar (Figure 2F).

Table 2. Anthocyanins (ACN) and total (TF), insoluble (IF), and soluble (SF) fiber intakes during the second phase of the experiment. Fecal dry weight and $\mathrm{pH}$ of the experimental groups ${ }^{*}$. Campinas (SP), Brazil, 2011.

\begin{tabular}{|c|c|c|c|c|c|c|c|c|c|c|}
\hline \multirow{2}{*}{ Parameters } & \multicolumn{2}{|c|}{$\mathrm{N}$} & \multicolumn{2}{|c|}{$\mathrm{HF}$} & \multicolumn{2}{|c|}{ HFJ1 } & \multicolumn{2}{|c|}{ HFJ2 } & \multicolumn{2}{|c|}{ HFJ4 } \\
\hline & $\mathrm{M}$ & SEM & $M$ & SEM & $\mathrm{M}$ & SEM & $\mathrm{M}$ & SEM & $M$ & SEM \\
\hline ACN intake (mg) & \multicolumn{2}{|r|}{-} & \multicolumn{2}{|c|}{ - } & \multicolumn{2}{|c|}{$99.72 \pm 2.71^{c}$} & \multicolumn{2}{|c|}{$207.7 \pm 7.89^{b}$} & \multicolumn{2}{|c|}{$458.40 \pm 22.96^{a}$} \\
\hline TF intake (g) & \multicolumn{2}{|c|}{$19.31 \pm 0.35^{a b}$} & \multicolumn{2}{|c|}{$18.94 \pm 0.46^{b}$} & \multicolumn{2}{|c|}{$19.19 \pm 0.52^{a b}$} & \multicolumn{2}{|c|}{$19.99 \pm 0.76^{a b}$} & \multicolumn{2}{|c|}{$22.05 \pm 1.10^{\mathrm{a}}$} \\
\hline IF intake (g) & \multicolumn{2}{|c|}{$19.31 \pm 0.35$} & \multicolumn{2}{|c|}{$18.94 \pm 0.46$} & \multicolumn{2}{|c|}{$19.00 \pm 0.52$} & \multicolumn{2}{|c|}{$19.59 \pm 0.74$} & \multicolumn{2}{|c|}{$21.17 \pm 1.06$} \\
\hline SF intake (g) & \multicolumn{2}{|c|}{-} & \multicolumn{2}{|c|}{-} & \multicolumn{2}{|c|}{$0.19 \pm 0.01^{c}$} & \multicolumn{2}{|c|}{$0.40 \pm 0.02^{b}$} & \multicolumn{2}{|c|}{$0.88 \pm 0.04^{a}$} \\
\hline Dried feces (g) & \multicolumn{2}{|c|}{$4.66 \pm 0.32^{c}$} & \multicolumn{2}{|c|}{$5.93 \pm 0.36^{b c}$} & \multicolumn{2}{|c|}{$5.58 \pm 0.26^{b c}$} & \multicolumn{2}{|c|}{$6.93 \pm 0.41^{a b}$} & \multicolumn{2}{|c|}{$7.69 \pm 0.59^{a}$} \\
\hline Fecal pH & \multicolumn{2}{|c|}{$6.62 \pm 0.02^{a}$} & \multicolumn{2}{|c|}{$6.19 \pm 0.08^{b c}$} & \multicolumn{2}{|c|}{$6.16 \pm 0.04^{b c}$} & \multicolumn{2}{|c|}{$6.13 \pm 0.03^{c}$} & \multicolumn{2}{|c|}{$6.44 \pm 0.07^{a}$} \\
\hline
\end{tabular}

Note: Different letters in lines indicate statiscal diference among the experimental groups ( $p<0.05)$. Parametric data (analysis of variance and Tukey's test) were expressed as mean \pm Standard Error of the Mean (SEM) $(n=6)$. ${ }^{*} \mathrm{~N}=$ Normal diet (AIN-93G) group; HF: High-Fat control diet group; HFJ1: High-Fat diet + 1\% Freeze-dried Jaboticaba Peel (FJP); HFJ2: High-Fat diet + 2\% FJP; and HFJ4: High-Fat diet + 4\% FJP. 
A

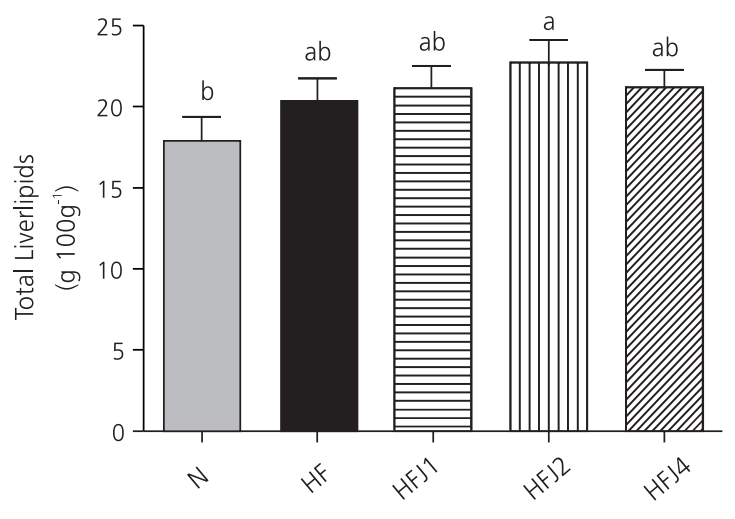

Experimental groups

\section{C}

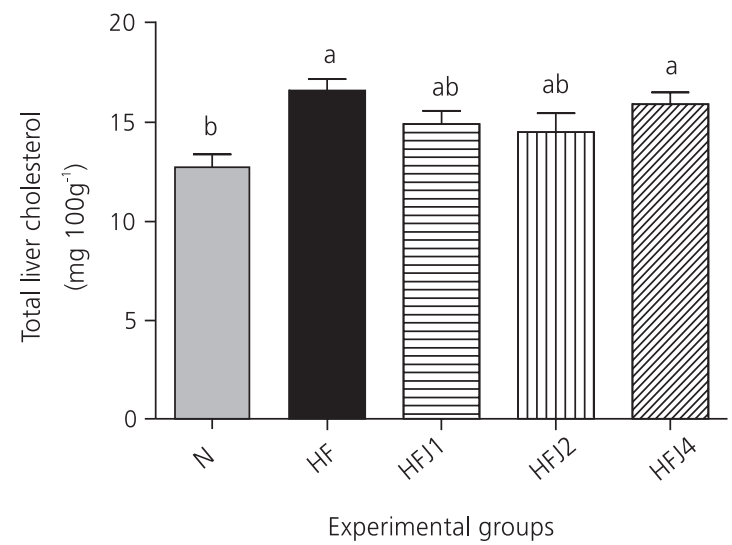

E

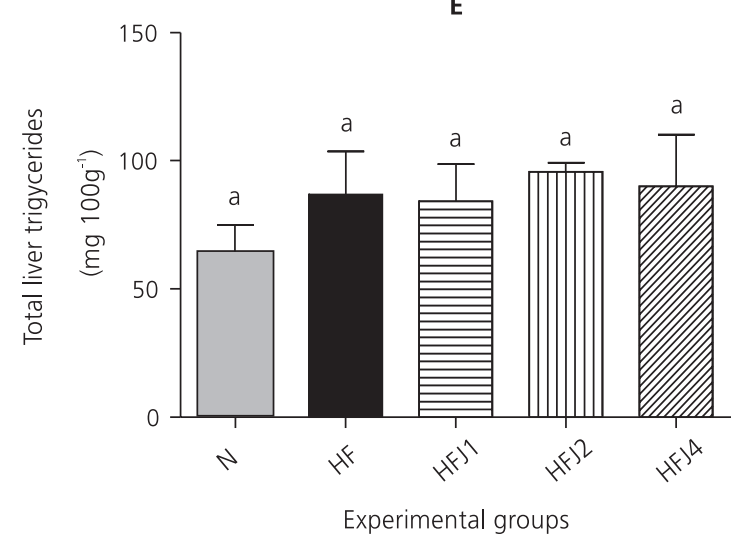

B

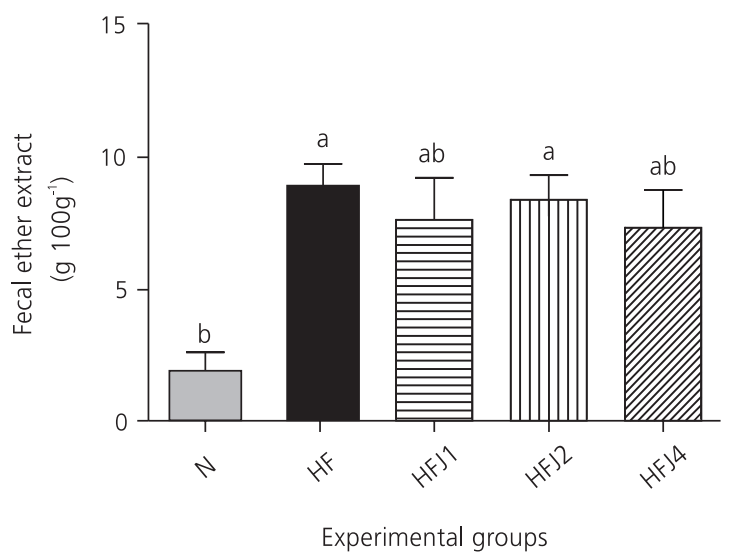

D

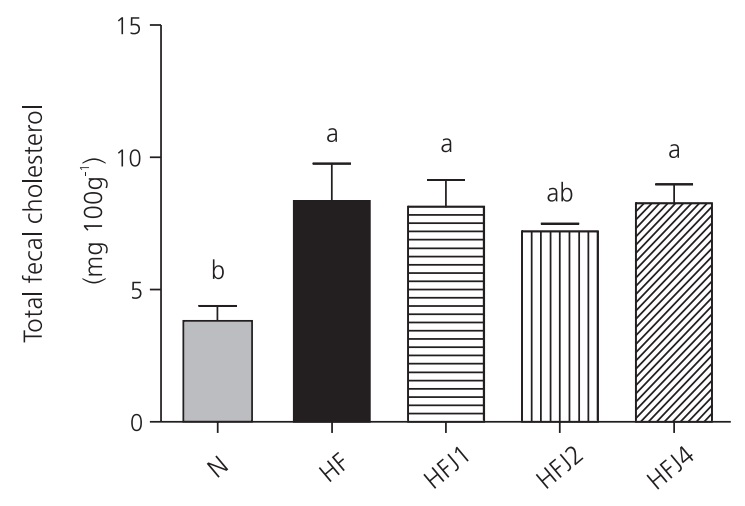

Experimental groups

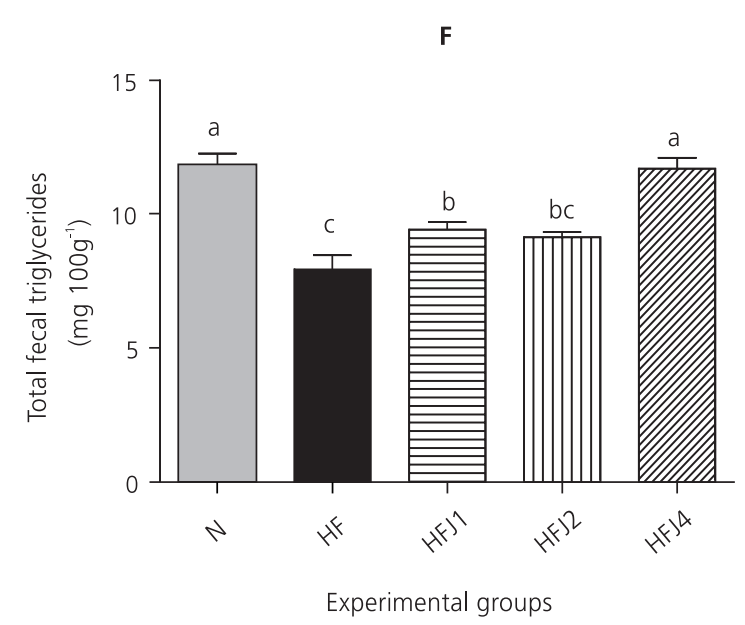

Figure 2. Total liver (A) and fecal (B) lipids; total liver (C) and fecal (D) cholesterol; total liver (E) and fecal (F) triglycerides of the experimental groups. Campinas (SP), Brazil, 2011.

Note: N: Normal-fat diet (AIN-93G) group; HF: High-Fat control diet group; HFJ1: animals fed HF + 1\% Freeze-dried Jaboticaba Peel (FJP); HFJ2: animals fed HF + 2\% FJP; and HFJ4: animals fed HF + 4\% FJP. Different letters in columns indicate statistical difference among the experimental groups. Parametric data (analysis of variance and Tukey's test) were expressed as mean \pm Standard Error of the Mean (SEM); nonparametric data in B, D and E (Kruskal-Wallis' and Dunn's tests) were expressed as median and ranges $(n=6) ; p<0.05$. 


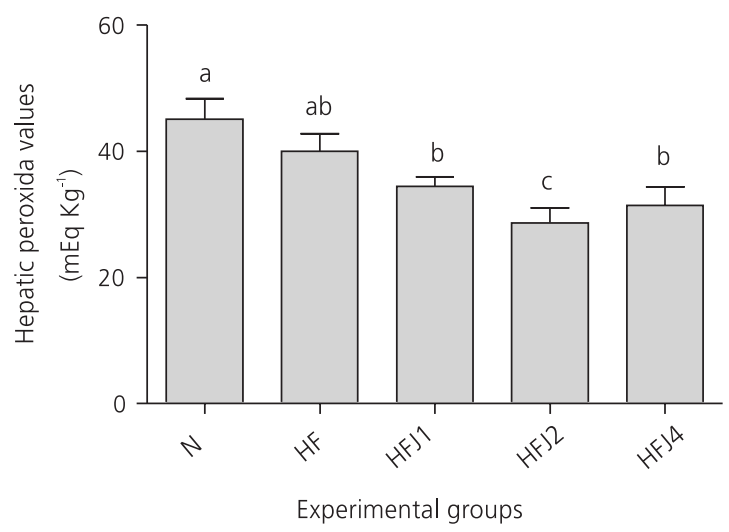

Figure 3. Hepatic lipid peroxidation in the experimental animals according to their peroxide values. The results are expressed on a dry-weight basis. Campinas (SP), Brazil, 2011.

Note: N: Normal-fat diet (AIN-93G) group; HF: High-Fat control diet group; HFJ1: animals fed High-Fat diet $+1 \%$ Freeze-dried Jaboticaba Peel (FJP); HFJ2: animals fed High-Fat diet $+2 \%$ FJP; and HFJ4: animals fed high-fat diet $+4 \%$ FJP. Different letters in columns indicate statistical difference among the experimental groups $(p<0.05)$. Parametric data (analysis of variance and Tukey's test) were expressed as mean \pm Standard Error of the Mean (SEM) $(n=6)$.

Liver lipid peroxidation: The peroxide values indicated that HFJ2 group had $28.36 \%$ fewer primary lipid peroxidation products in the liver than HF group (Figure 3).

\section{DISCUSSION}

This study indicates that $M$. jaboticaba peel may increase fecal triglycerides in obese rats, but does not reduce hepatic and serum lipid contents. Freeze-dried jaboticaba peel contains bioactive compounds that could be responsible for these findings, such as dietary fibers and polyphenols 3 . Although the studied diets had the same fiber content, the differences may stem from the soluble fiber content of freeze-dried jaboticaba peel, from its polyphenol content, and/or from other yet unknown substances. Moreover, the lard added to the high-fat diets is high in saturated fatty acids, which could hinder lipid metabolism in rats ${ }^{20}$. Additionally, in the present study lard promoted obesity in SD rats.
The impact of anthocyanins on the serum lipids of rats fed high-fat diets is controversial $7,10,21$. Kwon et al. ${ }^{7}$ found that SD rats fed $10 \%$ black soybean or $0.037 \%$ anthocyanin extract presented lower total serum cholesterol and triglyceride levels. However, studies with obese mice treated with a high-anthocyanin beverage or diet corroborate our findings ${ }^{10,21}$. Polyphenols have been found to reduce the total cholesterol of animals fed atherogenic diets ${ }^{5,12}$ and even healthy diets $^{4,22}$. Another study found that HFJ2 and HFJ4 diets were capable of increasing HDL-cholesterol ${ }^{6}$. Thus, although the total cholesterol levels of animals given freeze-dried jaboticaba peel did not decrease, an increase in HDL-cholesterol could reduce the risk of cardiovascular disease ${ }^{14}$.

Fatty liver and steatorrhea were expected in animals fed the high-fat diets. The freeze-dried jaboticaba peel did not reduce the total lipid content of the liver and/or increase fecal lipid content. Studies have shown that anthocyanins could reduce the lipid content of the liver but not change the lipid content of the feces ${ }^{5,10}$. Although HFJ2 group had a higher liver lipid content than $\mathrm{N}$ group, it had a lower lipid peroxidation value. The presence of polyphenols from freeze-dried jaboticaba peel in the liver may explain these findings. Polyphenols, especially anthocyanins, can donate electrons or hydrogen atoms and neutralize the peroxyl radicals that attack the lipids in cell membranes ${ }^{23}$. In addition, these compounds also correlate with better performance of the enzymes of the endogenous antioxidant system ${ }^{24}$. Bioavailability studies found that anthocyanins and their metabolites are largely present in the liver, being associated with high hepatic antioxidant capacity $^{25}$. Thus, the addition of $2 \%$ freeze-dried jaboticaba peel to the high-fat diet might have protected the liver from obesity-induced oxidative stress by providing exogenous and endogenous antioxidants, preventing lipid oxidation ${ }^{24}$.

Different anthocyanin doses did not affect the hepatic cholesterol levels of animals fed high-fat diets ${ }^{5,8}$. In our work, HFJ4 and HF groups reached the highest hepatic cholesterol levels. However, this could imply that freeze-dried jaboticaba peel is protective, since HFJ4 group 
consumed more food than HF group and did not experience proportional damage.

The higher food intake of HFJ4 group in the second phase of the experiment could also indicate that the HFJ4 diet was more palatable than the HF diet. On the other hand, these animals might have a dysfunction in the reward system in response to fat intake ${ }^{26}$, or an obesity-related disorder regarding leptin and anorexigenic peptide signaling in the hypothalamus ${ }^{27}$. Further studies on changes in the mechanisms of leptin signaling are needed to investigate this hypothesis.

The hepatic triglyceride contents of the experimental groups did not differ, but the absolute contents were higher in animals fed the high-fat diets, corroborating the serum triglyceride results. However, freeze-dried jaboticaba peel increased triglyceride excretion in the HFJ1 and HFJ4 groups. The triglyceride levels of obese HFJ4 animals were comparable to those of health animals in $\mathrm{N}$ group. The high fecal triglyceride content of HFJ4 group prevented their high food/ calorie intake to increase their serum and hepatic triglyceride levels.

High soluble fiber intake may have prevented high cholesterol/triglyceride absorption in HFJ4 group, or even cholesterol/triglyceride synthesis. Tsuda et al. ${ }^{10}$ found that mice given a high-fat diet with $2 \mathrm{~g} \mathrm{~kg}^{-1}$ of purple corn had lower lipogenic enzyme mRNA levels in their white adipose tissue. Additionally, Kim et al. ${ }^{5}$ found that the CYP 51 gene encoding lanosterol 14 $\alpha$ demethylase was down-regulated in the livers of golden Syrian hamsters fed a high-fat diet with $8 \%$ whole blueberry peel, indicating low cholesterol synthesis.

The dry weight of the fecal matter of HFJ2 and HFJ4 groups was high, probably reflecting their highest food intake during the last week. So far, there is evidence that the right proportion of soluble and insoluble dietary fibers in a meal has functional effects, such as reducing blood glucose variation and cholesterol levels. Soluble fibers are especially capable of forming complexes with dietary constituents, possibly producing larger food boluses that would increase the dry matter content of the feces ${ }^{28}$. The soluble fiber dose-dependent response shown by the groups fed freeze-dried jaboticaba peel corroborates this findings. Therefore, freeze-dried jaboticaba peel impacted the absorption of some nutrients, such as lipids, mainly triglycerides.

Curiously, the HFJ2 group had the lowest fecal $\mathrm{pH}$. Figure 2 shows that this group had higher fecal fatty acid content, which may explain this result. Another hypothesis is that soluble fiber and polyphenol contents of freeze-dried jaboticaba peel promoted the production of Short Chain Fatty Acids (SCFA) by gut microbiota. Higher SCFA production and a potentially higher delivery of SCFA, specifically butyrate, to the distal colon may be protective. Moreover, the production of propionate, another SCFA, helps to inhibit cholesterol synthesis in the liver ${ }^{29}$.

The fecal pH of HFJ4 group was not as low as expected. The higher polyphenol intake stemming from higher freeze-dried jaboticaba peel intake may have promoted enzymatic changes in the gut and microbiota ${ }^{30}$ that could reduce SCFA production ${ }^{31}$. Thus, the combination of fecal lipid content and ideal polyphenol and dietary fiber intakes may be responsible for the lowest fecal pH of HFJ2 group.

\section{CONCLUSION}

The addition of $1 \%, 2 \%$, and $4 \%$ freeze-dried jaboticaba peel to high-fat diets was not capable of decreasing the hepatic and serum cholesterol and triglyceride levels of obese animals. However, despite the higher lipid intake, the HFJ2 group had lower hepatic peroxide values. Fecal triglycerides increased in HFJ2 and HFJ4 groups, which showed a dose-dependent response to soluble fiber and anthocyanins intake. Concomitantly, the fecal pH of HFJ2 group decreased. More studies with different dietary fat contents and longer treatment periods with freeze-dried jaboticaba peel could better clarify the impact of this ingredient on the lipid profile of obese rats. 


\section{A C KNOWLEDGEMENTS}

The authors thank Conselho Nacional de Desenvolvimento Científico e Tecnológico, Coordenação de Aperfeiçoamento de Pessoal de Nível Superior and Fundação de Amparo à Pesquisa do Estado de São Paulo for sponsoring the study and Alice Vieira Leite Legatti for her kind cooperation.

\section{REFERE N CES}

1. Abe LT, Lajolo FM, Genovese MI. Potential dietary sources of ellagic acid and other antioxidants among fruits consumed in Brazil: Jabuticaba (Myrciaria jaboticaba (Vell.) Berg). J Sci Food Agric. 2012; 92(8):1679-87. doi: 10.1002/Jsfa.5531.

2. Lima ADB, Correa AD, Saczk AA, Martins MP, Castilho RO. Anthocyanins, pigment stability and antioxidant activity in jabuticaba [Myrciaria Cauliflora (Mart.) O. Berg]. Rev Bras Frutic. 2011; 33(3):877-87.

3. Leite-Legatti AV, Batista AG, Dragano NRV, Marques AC, Malta LG, Riccio MF, et al. Jaboticaba peel: Antioxidant compounds, antiproliferative and antimutagenic activities. Food Res Int. 2012; 49(1): 596-603. doi: 10.1016/j.foodres.2012.07.044.

4. Esteves EA, Oliveira LG, Pires ST, Batista AG, Dessimoni-Pinto NAV, Santana RC. Nutritional composition of Copaifera langsdorffii Desf. aril flour and its effect on serum lipids and glucose in rats. Food Res Int. 2011; 44(7):2357-61. doi: 10.1016/ j.foodres.2010.12.005.

5. Kim H, Bartley GE, Rimando AM, Yokoyama W. Hepatic gene expression related to lower plasma cholesterol in hamsters fed high-fat diets supplemented with blueberry peels and peel extract. J Agric Food Chem. 2010; 58(7):3984-91. doi 10.1021/Jf903230s.

6. Lenquiste SA, Batista AG, Marineli RD, Dragano NRV, Marostica MR. Freeze-dried jaboticaba peel added to high-fat diet increases HDL-cholesterol and improves insulin resistance in obese rats. Food Res Int. 2012; 49(1):153-60. doi: 10.1016/j. foodres.2012.07.052.

7. Kwon SH, Ahn IS, Kim SO, Kong CS, Chung HY, Do MS, et al. Anti-obesity and hypolipidemic effects of black soybean anthocyanins. J Med Food. 2007; 10(3):552-6. doi: 10.1089/Jmf.2006.147.

8. Jayaprakasam B, Olson LK, Schutzki RE, Tai MH, Nair MG. Amelioration of obesity and glucose intolerance in high-fat-fed C57BL/6 mice by anthocyanins and ursolic acid in Cornelian cherry
(Cornus mas). J Agric Food Chem. 2006; 54(1):243-8. doi: 10.1021/Jf0520342.

9. Prior RL, Wu XL, Gu LW, Hager TJ, Hager A, Howard LR. Whole berries versus berry anthocyanins: Interactions with dietary fat levels in the C57BL/6J mouse model of obesity. J Agric Food Chem. 2008; 56(3):647-53. doi: 10.1021/Jf0719930.

10. Tsuda T, Horio F, Uchida K, Aoki H, Osawa T. Dietary cyanidin 3-O-beta-D-glucoside-rich purple corn color prevents obesity and ameliorates hyperglycemia in mice. J Nutr. 2003; 133(7):2125-30.

11. Lima AJBC, Corrêa AD, Alves APC, Abreu CMP; Dantas-Barros AM. Caracterização química do fruto jabuticaba (Myrciaria cauliflora Berg) e de suas frações. Arch Latinoam Nutr. 2008; 58(4):416-21.

12. Kalt W, Foote K, Fillmore SAE, Lyon M, Van Lunen TA, McRae KB. Effect of blueberry feeding on plasma lipids in pigs. Br J Nutr. 2008; 100(1):70-8. doi: 10.1017/S0007114507877658.

13. Leite AV, Malta LG, Riccio MF, Eberlin MN, Pastore GM, Marostica MR. Antioxidant potential of rat plasma by administration of freeze-dried jaboticaba peel (Myrciaria jaboticaba Vell Berg). J Agric Food Chem. 2011; 23;59(6):2277-83. doi: 10.1021/Jf103 $181 x$.

14. Aviram M, Fuhrman B. Wine flavonoids protect against LDL oxidation and atherosclerosis. Alcohol Wine Health Dis. 2002; 957:146-61. doi: 10.1111/j.17 49-6632.2002.tb02913.x.

15. Marques AY, Dragano NR, Lenquiste SA, Batista AG, Palazzo CC, Maróstica Júnior MR. Freeze-dried jaboticaba peel powder rich in anthocyanins did not reduce weight gain and lipid content in mice and rats. Archi Latinoamer Nutr. 2012; 62(1):37-43.

16. Reeves PG, Nielsen FH, Fahey GC. Ain-93 purified diets for laboratory rodents - final report of the American Institute of Nutrition Ad Hoc Writing Committee on the Reformulation of the Ain-76a Rodent Diet. J Nutr. 1993; 123(11):1939-51.

17. Bligh EG, Dyer W. J. A Rapid method of total lipid extraction and purification. Canadian J Biochem Physiol. 1959; 37(8):911-7.

18. Association of Official Analytical Chemists. Official methods of analysis of Association of Official Analytical Chemists international. Arlington: AOAC; 1995.

19. Folch J, Less M, Sloane-Stanley, GHA. Simple method for isolation and purification of total lipids from animals tissues. J Biol Chem. 1957; 226(1):407-11.

20. Castro GSF, Almeida BB, Leonardi DS, Ovídio PP, Jordão AA. Association between hepatic cholesterol and oleic acid in the liver of rats treated with partially hydrogenated vegetable oil. Rev Nutr. 
2012; 25(1):45-56. doi: 10.1590/S1415-52732012 000100005.

21. Prior RL, Wilkes SE, Rogers TR, Khanal RC, Wu XL, Howard LR. Purified blueberry anthocyanins and blueberry juice alter development of obesity in mice fed an obesogenic high-fat diet. J Agric Food Chem. 2010; 14;58(7):3970-6. doi: 10.1021/Jf902852d.

22. Souza MO, Silva M, Silva ME, Oliveira RP, Pedrosa ML. Diet supplementation with acai (Euterpe oleracea Mart.) pulp improves biomarkers of oxidative stress and the serum lipid profile in rats. Nutrition. 2010; 26(7-8):804-10. doi: 10.1016/j.nut.2009.09.007.

23. Prior RL. Fruits and vegetables in the prevention of cellular oxidative damage. Am J Clin Nutr. 2003; 78(3):570s-8s.

24. Lee SJ, Choi SK, Seo JS. Grape skin improves antioxidant capacity in rats fed a high fat diet. Nutr Res Pract. 2009; 3(4):279-85. doi: 10.4162/nrp.200 9.3.4.279.

25. Mazza G, Kay CD, Cottrell T, Holub BJ. Absorption of anthocyanins from blueberries and serum antioxidant status in human subjects. J Agric Food Chem. 2002; 50(26):7731-7. doi: 10.1021/Jf020690l.

26. Johnson PM, Kenny PJ. Dopamine D2 receptors in addiction-like reward dysfunction and compulsive eating in obese rats. Nat Neurosci. 2010; 13(5): 635-41. doi: 10.1038/nn.2519.
27. Jequier E. Leptin signaling, adiposity, and energy balance. Ann N Y Acad Sci. 2002; 967:379-88.

28. Batista AG, Esteves EA, Dessimoni-Pinto NAV, Oliveira LG, Pires ST, Santana RC. Chemical composition of jatobá-do-cerrado (Hymenaea stigonocarpa Mart.) flour and its effect on growth of rats. Alim Nutr. 2011; 22(2):173-80.

29. Wong JMW, de Souza R, Kendall CWC, Emam A, Jenkins DJA. Colonic health: Fermentation and short chain fatty acids. J Clin Gastroenterol. 2006; 40(3):235-43. doi: 10.1097/00004836-2006030 00-00015.

30. Jurgoñski A, Juœkiewicz J, Zduñczyk Z. An anthocyanin-rich extract from Kamchatka honeysuckle increases enzymatic activity within the gut and ameliorates abnormal lipid and glucose metabolism in rats. Nutrition. 2013; 29(6):898-902. doi: 10.1016/j.nut.2012.11.006.

31. Silva JK, Cazarin CBB, Colomeu TC, Batista ÂG, Meletti LMM, Paschoal JAR, et al. Antioxidant activity of aqueous extract of passion fruit (Passiflora edulis) leaves: In vitro and in vivo study. Food Res Int. 2013; 53:882-90. doi: 10.1016/j.foodres.201 2.12.043.

Received on: $14 / 12 / 2012$ Final version on: 7/3/2013 Approved on: 24/6/2013

\section{ERRATA}

No artigo "Jaboticaba (Myrciaria jaboticaba (Vell.) Berg.) peel improved triglycerides excretion and hepatic lipid peroxidation in high-fat-fed rats" publicado no número 5, volume 26, Revista de Nutrição, na página 571, onde se lê:

"Jaboticaba (Myrciaria jaboticaba (Vell.) Berg.) peel increased triglycerides excretion and hepatic lipid peroxidation in high-fat-fed rats"

Leia-se:

"Jaboticaba (Myrciaria jaboticaba (Vell.) Berg.) peel improved triglycerides excretion and hepatic lipid peroxidation in high-fat-fed rats"

No mesmo artigo, na página 577, onde de lê:

"As unidades na Figura 2 (C, D, E, F) de g $100 \mathrm{~g}^{-1 "}$

\section{Leia-se:}

"As unidades na Figura 2 (C, D, E, F) mg 100g-1" 